\title{
CONFERENCE OF PhD STUDENTS IN Computer SCIENCE
}

Guest Editor:

\author{
Attila Kertész \\ Department of Software Engineering \\ University of Szeged \\ Szeged, Hungary \\ keratt@inf.u-szeged.hu
}





\section{Preface}

The 11th Conference of PhD Students in Computer Science (CSCS) was organized by the Institute of Informatics of the University of Szeged (SZTE) and held in Szeged, Hungary, between June 25-27, 2018.

The members of the Scientific Committee were the following representatives of the Hungarian doctoral schools in computer science: János Csirik (Co-Chair, SZTE), Lajos Rónyai (Co-Chair, SZTAKI, BME), Péter Baranyi (SZE), András Benczúr (ELTE), András Benczúr (SZTAKI), Hassan Charaf (BME), Tibor Csendes (SZTE), László Cser (BCE), Erzsébet Csuhaj-Varjú (ELTE), József Dombi (SZTE), István Fazekas (DE), Zoltán Fülöp (SZTE), Aurél Galántai (ÓE), Zoltán Gingl (SZTE), Tibor Gyimóthy (SZTE), Katalin Hangos (PE), Zoltán Horváth (ELTE), Márk Jelasity (SZTE), Zoltán Kása (Sapientia EMTE), László Kóczy (SZE), János Levendovszki (BME), Gyöngyvér Márton (Sapientia EMTE), Branko Milosavljevic (UNS), Valerie Novitzka (TUKE), László Nyúl (SZTE), Marius Otesteanu (UPT), Attila Pethő (DE), Vlado Stankovski (UNILJ), Tamás Szirányi (SZTAKI), Péter Szolgay (PPKE), János Sztrik (DE), János Tapolcai (BME), János Végh (ME), and Daniela Zaharie (UVT). The members of the Organizing Committee were: Attila Kertész (Chair), Balázs Bánhelyi, Tamás Gergely, and Zoltán Kincses.

There were more than 55 participants and 52 talks in several fields of computer science and its applications (13 sessions). The talks were going in sections in Artificial Intelligence, Static Analysis, Cloud Computing I., Testing, Cloud Computing II., Image Processing I., Education, Image Processing II., Optimization, Algorithms, Programming Languages, Evaluation, Business Process. The talks of the students were completed by 3 plenary talks of leading scientists: Bálint Daróczy (MTA SZTAKI, Hungary), Michael C. Mackey (McGill University, Canada), and Massimiliano Di Penta (University of Sannio, Italy).

The open-access scientific journal Acta Cybernetica offered PhD students to publish the paper version of their presentations after a careful selection and review process. Altogether 24 manuscripts were submitted for review, out of which 10 were accepted for publication in the present special issue of Acta Cybernetica. 2 papers were published in the previous issue, and 2 additional papers are planned to be published in a future issue.

The full program of the conference, the collection of the abstracts and further information can be found at http://www.inf.u-szeged.hu/ cscs.

On the basis of our repeated positive experiences, the conference will be organized in the future, too. According to the present plans, the next meeting will be held around the end of June 2020 in Szeged. 